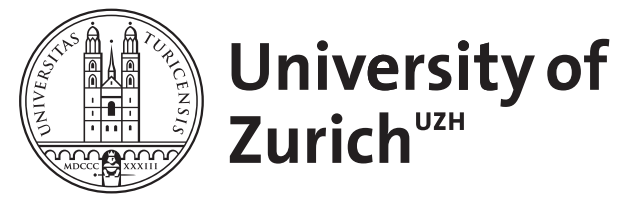
Archive

University of Zurich

University Library

Strickhofstrasse 39

CH-8057 Zurich

www.zora.uzh.ch

Year: 2014

\title{
An evolutionary and developmental perspective on the loss of regionalization in the limbs of derived ichthyosaurs
}

Maxwell, Erin E ; Scheyer, Torsten M ; Fowler, Donald A

DOI: https://doi.org/10.1017/S0016756812001070

Posted at the Zurich Open Repository and Archive, University of Zurich ZORA URL: https://doi.org/10.5167/uzh-89629

Journal Article

Published Version

Originally published at:

Maxwell, Erin E; Scheyer, Torsten M; Fowler, Donald A (2014). An evolutionary and developmental perspective on the loss of regionalization in the limbs of derived ichthyosaurs. Geological Magazine, 151(1):29-40.

DOI: https://doi.org/10.1017/S0016756812001070 


\title{
An evolutionary and developmental perspective on the loss of regionalization in the limbs of derived ichthyosaurs
}

\author{
ERIN E. MAXWELL* $\dagger$, TORSTEN M. SCHEYER* \& DONALD A. FOWLER \\ *Paläontologisches Institut und Museum der Universität Zürich, Karl Schmid-Strasse 4, 8006 Zürich, Switzerland \\ $\ddagger$ Redpath Museum, McGill University, 859 Sherbrooke St West, Montreal QC Canada H3A 2K6
}

(Received 31 July 2012; accepted 11 December 2012; first published online 3 May 2013)

\begin{abstract}
Ichthyosaurs, a lineage of extinct Mesozoic marine reptiles, have garnered attention in both the palaeontological and developmental literature for the unique limb morphology seen in derived genera. These morphologies include an increase in the number of phalanges per digit (hyperphalangy) and in the number of digits (hyperdactyly), but most interestingly also a shift in element identity. Elements distal to the stylopodium acquire characteristics of mesopodial elements, such as a rounded, nodular shape and a loss of perichondral bone on the anterior and posterior surfaces. Here, we examine numerous aspects of the loss of proximodistal identity in ichthyosaur limbs including phylogenetic progression of the loss of perichondral bone, histology and microstructure of the elements retaining perichondral bone in derived taxa, and correlates of intraspecific variation in degree of perichondral bone reduction in a derived ichthyosaur, Stenopterygius quadriscissus. Results show that loss of limb element identity occurred progressively over ichthyosaurian evolution, and the notches seen on the anterior surface of limb elements in derived ichthyosaurs are homologous to the long bone shafts in terrestrial tetrapods. Variation in the number of notches in S. quadriscissus can best be explained through delayed ossification of the anterior perichondrium, indicating a heterochronic component to the loss of identity. We propose a developmental mechanism - gradual expansion of the polyalanine region of HoxD13 over ichthyosaurian evolution - to explain the progressive loss of limb regionalization as well as the heterochronic delay in perichondral ossification.
\end{abstract}

Keywords: Ichthyosauria, Stenopterygius, limb evolution, bone histology, heterochrony, HoxD13, intraspecific variation.

\section{Introduction}

Ichthyosaurs are one of the groups of secondarily aquatic tetrapods most highly modified for an aquatic way of life. It was recognized as a unique lineage over 200 years ago, thanks in part to the collecting efforts of the Anning family (reviewed by Evans, 2010), and even the earliest interpretations of ichthyosaurian limbs regarded them as fish-like and specialized for a marine way of life (De la Beche \& Conybeare, 1821). The limbs of derived ichthyosaurs are still regarded as one of the most unique characteristics of this group, and receive a disproportionate amount of research attention from specialists for this reason (Johnson, 1979; Caldwell, 1997a,b; Motani, 1997, 1998, 1999a; Maisch \& Matzke, 1998; Maxwell, 2012). However, in addition to these papers examining morphology, homology and variation in the appendicular skeleton, the limbs of derived ichthyosaurs represent a morphological endpoint for the phenomena of hyperphalangy and hyperdactyly - that is, they represent a classic example of morphospace occupation that is dissimilar to anything naturally occurring in an extant taxon. This has led to the inclusion of this clade as a comparative point in studies on the genetics of limb patterning in extant tetrapods (e.g. Caldwell, 2002; Fedak \&

$\nmid$ Author for correspondence: emaxwell@ualberta.ca
Hall, 2004; Archer, Dowthwaite \& Francis-West, 2007; Zhu et al. 2010). Relatively few studies consider the identity of the resulting elements (e.g. Wagner \& Chiu, 2001; Woltering \& Duboule, 2010). Element identity is an intriguing problem in the highly modified ichthyosaur limb, influencing both ingroup homology determination and understanding of the stability of proximodistal patterning in vertebrate limbs.

Although ichthyosaur limbs are extensively modified for aquatic locomotion, the typical tetrapod pattern is conserved in the most basal forms (Nicholls \& Brinkman, 1995; Motani, 1997). However, the proximal elements (stylopodium, zeugopodium) as well as the metapodials and phalanges are shortened and the manus is elongated through the addition of elements, as is typical for secondarily aquatic tetrapods (Thewissen \& Taylor, 2007). In derived forms, these stereotypical changes are taken to an extreme, and proximodistal regionalization has become blurred: clear zeugopodial, mesopodial, metapodial and phalangeal identities are absent and elements are dorsoventrally flattened and nodular, lacking perichondral bone not only on the proximal and distal articular surfaces, but also on the anterior and posterior surfaces (Caldwell, 1997a,b) ('mesopodialization': Wagner \& Chiu, 2001). Only some elements of the leading-edge digit retain perichondral bone on their anterior surface (digit II: Motani, 1999a), resulting in a distinctive 

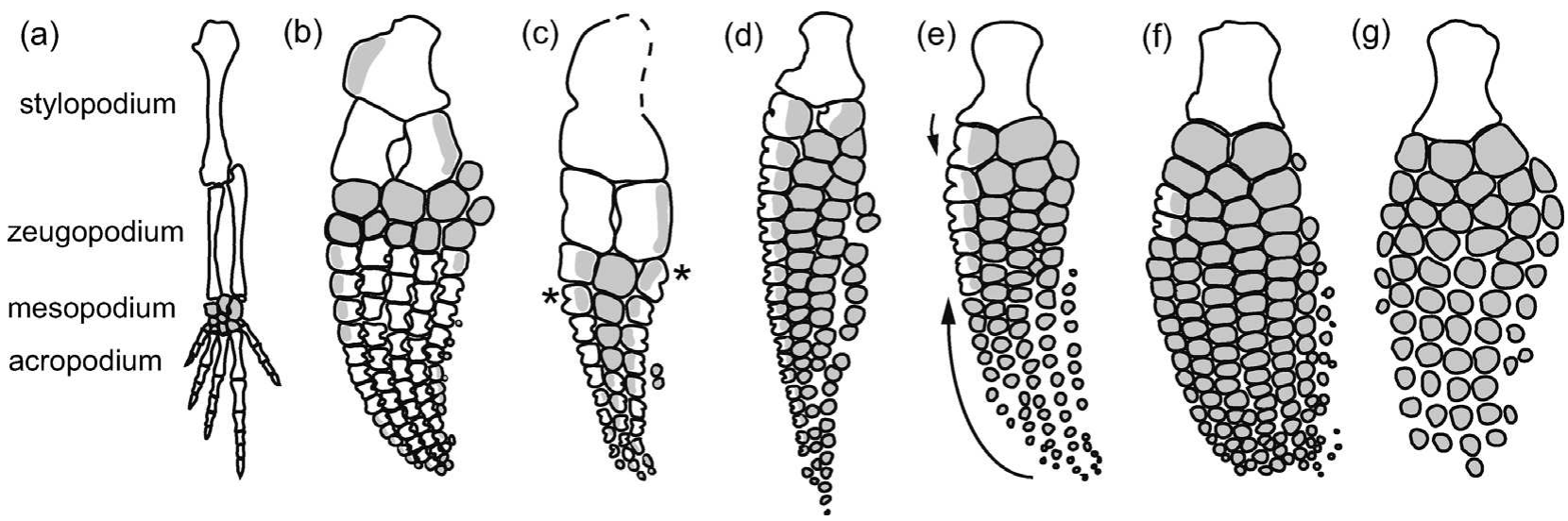

Figure 1. Sequence of perichondral bone loss in forelimbs of selected ichthyosaurs. Grey shading denotes the area of the limb from which perichondral bone is absent. (a) Petrolacosaurus, representing the terrestrial diapsid condition. Modified from Reisz (1981); (b) Mixosaurus cornalianus (basal grade), modified from Maxwell (2012); (c) Toretocnemus (intermediate grade), modified from McGowan \& Motani (2003), asterisks denote acquisition of a notched element morphology in the mesopodium. (d) Temnodontosaurus trigonodon (non-ophthalmosaurid parvipelvian grade), (SMNS 50000); (e) Stenopterygius quadriscissus (nonophthalmosaurid parvipelvian grade), modified from Maxwell (2012), arrows denote intraspecific trends in perichondral bone loss; (f) Ichthyosaurus communis (non-ophthalmosaurid parvipelvian), modified from Maxwell (2012); (g) Ophthalmosaurus (ophthalmosaurid grade), modified from McGowan \& Motani (2003).

notched morphology (C-shaped invagination: Caldwell, 1997a; peripheral 'shaft': Motani, 1999b). Although intraspecific and asymmetric variability is widespread (McGowan, 1974; Johnson, 1979), the proximodistal location of the notched elements can have diagnostic value (McGowan \& Motani, 2003). For instance, the absence of notched elements is considered to be a feature uniting ophthalmosaurids, a diverse clade comprising most Middle Jurassic - Cretaceous ichthyosaurs (Fischer et al. 2011) (Fig. 1). Although the notched morphology is distinctive, the homology and function of this character is debated (Johnson, 1979; Caldwell, 1997a; Motani, 1999b) and has implications for proximodistal identity determination within the limb.

Two hypotheses have been proposed to explain the notches in ichthyosaur limb elements. Johnson (1979) suggested that notches transmitted nerves or blood vessels to the Mm. extensor and flexor carpi radialis. She further speculated that the notch might form the posterior wall of a foramen completed anteriorly by fibrocartilage (Johnson, 1979). This speculation receives support from e.g. Shonisaurus, where the proximal and distal margins of the phalanx curl together anterior to the notch and are almost in contact (Camp, 1980). Caldwell (1997a) also supported notching as an adaptation protecting rerouted nerves and blood vessels following the loss of the antebrachial space. This hypothesis is not mutually exclusive with the hypothesis of homology presented below, but does not explicitly require the notches to be homologized with the shaft of long bones. As it relies on soft tissue anatomy, it cannot be directly tested.

The second hypothesis is one of homology. Huene (1922) proposed that the anterior notching of elements was a primitive feature, a retained vestige of the dumbbell shape of long bones in the terrestrial condition.
This view was supported by Motani (1999b), who tentatively considered the notches to be homologous to the shafts of long bones. However, notching of the carpal and tarsal elements, sometimes in the absence of notching of elements considered to be long bones (e.g. zeugopodials, metapodials, phalanges) (Motani, 1999a) needs to be addressed.

In this contribution, we draw on multiple lines of evidence to examine the evolution, structure and function of notching in the limb elements of derived ichthyosaurs. We summarize the taxonomic and proximodistal distribution of notches across the clade in order to infer the evolutionary history of this morphology. We treat notching of limb elements as a morphological property of the elements within an accepted positional framework (Motani, 1999a) rather than as a marker of element identity, which is appropriate given both the evolutionary flexibility in location and the levels of intraspecific variability reported. We also examine the histology of notched elements to assess morphological divergence in bone microstructure along the anteroposterior axis and potential functional drivers. Lastly, we identify factors influencing intraspecific variability in the distribution of notched limb elements in the Early Jurassic ichthyosaur Stenopterygius quadriscissus. Based on the combined results of the preceding three sections, we propose a developmental mechanism underlying the evolutionary changes observed.

\section{Materials and methods}

\section{2.a. Institutional abbreviations}

MHH - Urwelt Museum Hauff, Holzmaden, Germany; SMNS - Staatliches Museum für Naturkunde Stuttgart, Germany. 
(a)

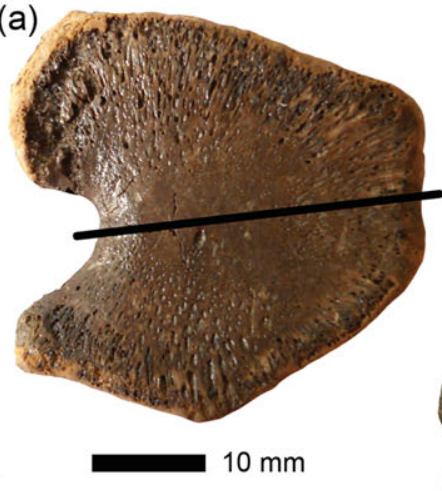

(b)

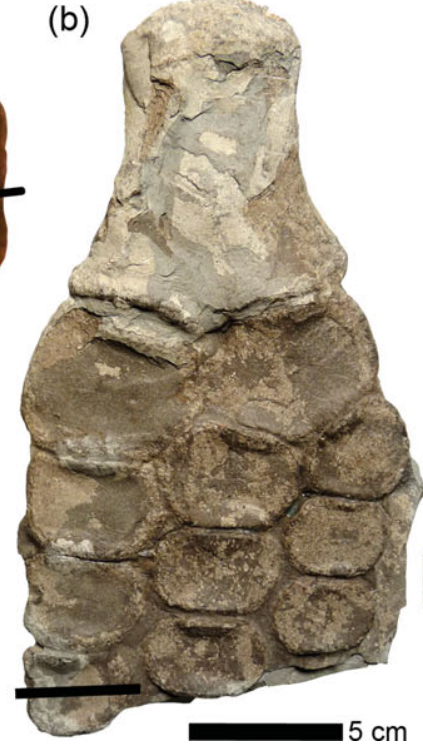

(c)

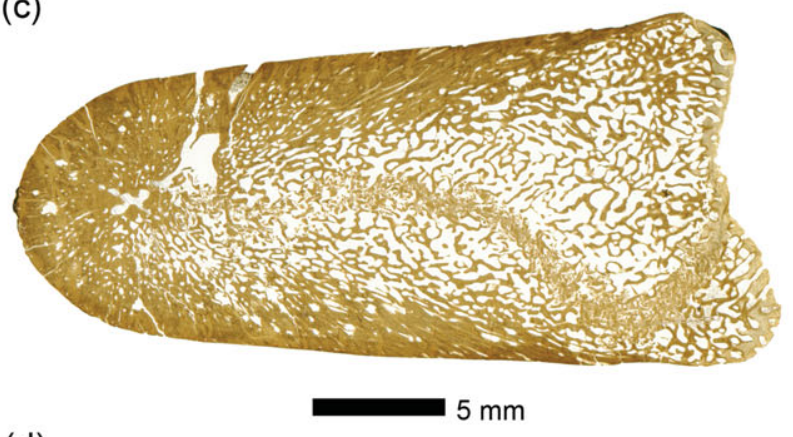

(d)

Figure 2. (Colour online) (a) Tibia of SMNS 51130, Stenopterygius cf. uniter, and (b) flipper of SMNS 50329, Temnodontosaurus cf. trigonodon prior to sectioning, with the plane of sectioning indicated. (c) Microstructural overview of tibia (SMNS 51130) and (d) metacarpal II (SMNS 50329); anterior is to the left.

\section{2.b. Phylogenetic variation in proximodistal regionalization}

Owing to their taxonomic utility, ichthyosaur limbs are relatively well known and thoroughly described in the literature, so we can supplement the observations presented by Caldwell $(1997 b, 2002)$ to gain a better understanding of the pattern of loss of perichondral bone (and thus notching) in the digits and the gain of perichondral bone in the mesopodial region. We frame the evolutionary pattern as a transition series rather than as an optimized character, owing in part to controversies regarding the interrelationships of Triassic ichthyosaurs (e.g. Sander et al. 2011; Thorne, Ruta \& Benton, 2011), but also because of the suspected influence of individual age and degree of ossification (Johnson, 1977) on the pattern observed. We divided ichthyosaurs into four grades: basal (e.g. grippidians, mixosaurids), intermediate (more derived than mixosaurids, but basal to parvipelvians sensu Sander et al. 2011), nonophthalmosaurid parvipelvians and ophthalmosaurids. The terms 'peripheral' and 'contiguous' are used in the sense of Motani (1999b) to refer to the morphological state observed along the anterior and posterior margins of the flipper and the centre, respectively.

\section{2.c. Histology and microstructure of long bones with partial perichondral reduction}

We conducted a preliminary analysis to examine whether differences in microstructure exist between the periosteum of the notched edge and the periosteum of the dorsal and ventral surfaces of mesopodialized elements. We sampled a tibia (SMNS 51130) from the Posidonia Shale referable to Stenopterygius cf. uniter (Fig. 2a). In addition, we sampled a metacarpal II (mcII) referable to Temnodontosaurus $\mathrm{cf}$. trigonodon (SMNS
50329) (Fig. 2b). Both elements externally exhibited notching of the anterior surface.

Although several ichthyosaur limb elements have been examined histologically, none of these exhibited notching in the sense discussed here. Comparative histological information is available for humeri (Kiprijanoff, 1881; de Buffrénil \& Mazin, 1990; Canoville \& Laurin, 2010; Kolb, Sánchez-Villagra \& Scheyer, 2011), the tibia of a Triassic intermediate-grade taxon retaining both the contiguous and peripheral shaft (de Buffrénil \& Mazin, 1990), as well as zeugopodial and more distal limb elements of ophthalmosaurids (Kiprijanoff, 1881; Lopuchowycz \& Massare, 2002).

The sampling of the bones followed standard petrographic thin-sectioning procedures, as were outlined by Chinsamy \& Raath (1992). Both the tibia and the mcII were sectioned parallel to the anteroposterior axis, through the mid-point of the anteriorly directed notch to elucidate the structure and distribution of periosteal versus endosteal bone (Fig. 2a, b). The thinsections were analyzed using a composite polarizing microscope Leica DM 2500 M equipped with a Leica DFC420 C digital camera.

\section{2.d. Intraspecific variation in Stenopterygius quadriscissus}

In order to investigate the relationship between function, ontogeny and the notched morphology of limb elements, we examined correlation patterns between the number of notches and predictor variables (size, number of phalanges in the longest digit, stratigraphy and number of notches in the serial homologue) in the fore- and hind limbs of the parvipelvian ichthyosaur Stenopterygius quadriscissus, from the Lower Jurassic Posidonia Shale of Baden-Württemberg, Germany. See Table S1 in the online Supplementary Material at 
http://journals.cambridge.org/geo for a list of specimens examined. We selected these variables based on previous studies indicating that they influenced aspects of limb morphology in secondarily aquatic tetrapods more generally and Stenopterygius in particular (Johnson, 1977; Dawson, 2003; Maxwell, 2012; Maxwell, Fernández \& Schoch, 2012; Maxwell \& Dececchi, 2012).

We evaluated the relationship between number of notches, number of phalanges in digit II and size (using length of the lower jaw as a proxy; McGowan, 1973) for the fore- and hind limbs separately to maximize sample size, and then together to test the effect of serial homology. Because of uncertainty regarding independence of the variables (stage of ontogeny and digital length appear to be slightly correlated: Maxwell, 2012), we examined relationships using non-parametric partial correlation (Kendall's tau) implemented in R (R Development Core Team, 2011). Sequential Bonferroni correction for multiple comparisons was applied as per Quinn \& Keough (2002). When the number of notches or phalanges varied within an individual, the average was used for statistical purposes. Stratigraphy was not included in the correlation analysis because examination of the data suggested that although the number of notched elements was greatest in the stratigraphically youngest specimens (falciferum Zone, late elegans Subzone) there was not a linear increase through the sampled interval.

\section{Results}

\section{3.a. Phylogenetic variation in proximodistal regionalization}

Concerning our proposed transition series (Fig. 1), we suggest that the first transition involved a reduction in perichondral bone in digits I and $\mathrm{V}$; the second involved reduction of perichondral bone in the central digits in a proximal to distal sequence and in the marginal digits in a contiguous to peripheral sequence (data are presented in Table S2 in the online Supplementary Material at http://journals.cambridge.org/geo). Concurrent with the latter stage, the peripheral surface of the anterior mesopodials became notched, likely following a distal to proximal sequence. The next major change was the dissociation between the fore- and hind limbs, with the evolutionary loss of perichondral bone in the hind limb delayed relative to its loss in the forelimb. The dissociation between the forelimb and hind limb coincides approximately with the first appearance of the clade Parvipelvia, but the timing could be an artefact of a poor Middle-Late Triassic record: there is some evidence that extent of notching in the forelimb was reduced relative to the hind limb in the intermediategrade genus Besanosaurus (E. Maxwell, pers. obs.; Dal Sasso \& Pinna, 1996). The decoupling between the pattern in the fore- and hind limbs is followed by the loss of the contiguous shaft of the radius (Fig. 1d), then that of the ulna (Fig. 1e). Subsequent trends in perichondral bone loss in Early Jurassic ichthyosaurs are less clearly directional.

All Early Jurassic genera show variation in the number of notches between species. Two patterns of reduction in the number of notches are observed, but the data are not easily interpreted in a phylogenetic context. The first pattern is more widespread and involves a progressive reduction of notching of the leadingedge digit in a distal to proximal direction (e.g. Temnodontosaurus platyodon, Hauffiopteryx, Leptonectes tenuirostris, Excalibosaurus and Eurhinosaurus). The second pattern is similar, but involves the loss of notches not only from distal to proximal in the phalanges, but also from proximal to distal in the radius and proximal carpals. This second trend is seen in Stenopterygius (Fig. 1e; except in S. aaleniensis) and Ichthyosaurus (Fig. 1f; except in the hind limb of I. conybeari) (Table S2 in the online Supplementary Material at http://journals.cambridge.org/geo).

\section{3.b. Histology and microstructure of long bones with partial perichondral reduction}

In the thin-section of the Stenopterygius tibia, periosteal bone is present along the anterior (Fig. 3ac), dorsal and ventral surfaces of the element. The posterior surface, the margin that articulates with the fibula, lacks a periosteal layer but is instead covered by a layer of articular calcified cartilage (Fig. 3d). The periosteal layer is thickest towards the anterior end of the element and thins posteriorly. In the mcII of Temnodontosaurus, the articular cartilage is also seen along the posterior margin in the thin-section in the region that would have articulated with mcIII (Fig. 3e), whereas the dorsal, ventral and the anterior notched regions (Fig. 3f) of the element show periosteal bone composed of fibrolamellar bone (Fig. $3 \mathrm{~g}-\mathrm{h}$ ). The internal part of both elements is composed of secondary trabeculae and the articular surfaces are slightly concave. Furthermore, the periosteal layers taper off just before the posterior articular surface, so that the adjacent dorsal and ventral surface areas are also composed of calcified cartilage (Fig. 2c-d). The microstructure of the dorsal and ventral periosteal layer is identical to the periosteal layer of the notched region, and both the fibrolamellar bone matrix and the vascularization pattern can be continuously traced through the sections. Sharpey's fibres are present throughout the periosteal bone.

Both elements experienced dorsoventral compaction. In the mcII, crushing is much stronger, leading to the collapse of internal trabecular structures and a displacement of the anterior periosteal bone (Fig. 2d). In the tibia, crushing is minimal, restricted to a thin area within the cancellous bone (visible as a meandering thin band of trabecular 'debris') (Fig. 2c). The concavity of the articular (posterior) margin of the tibia is thus genuine and not a taphonomic artefact. Owing to the stronger degree of structural collapse, this feature is not so clear in the mcII. Although the 

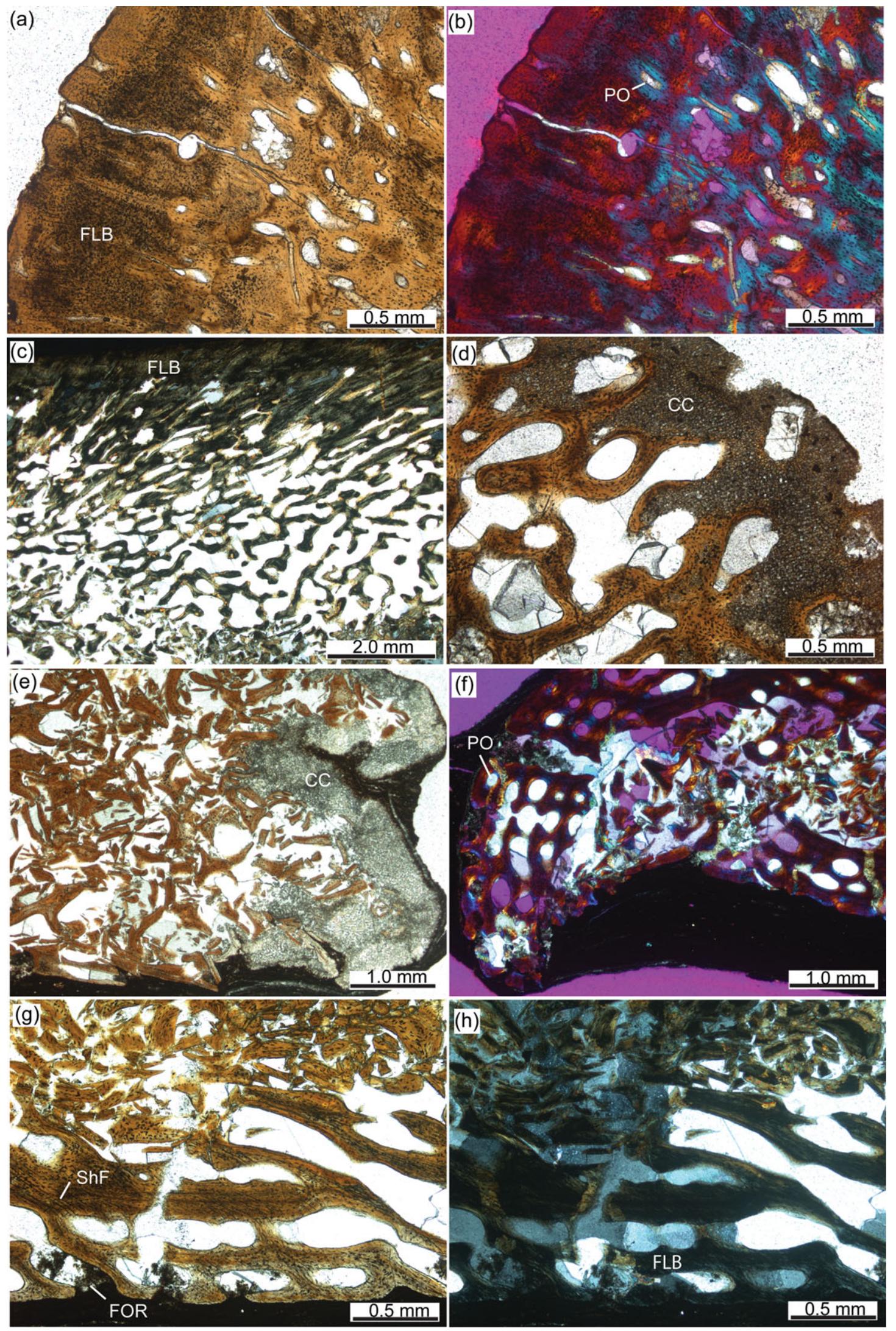

Figure 3. (Colour online) (a-d) Tibia of SMNS 51130, Stenopterygius $\mathrm{cf}$. uniter; (e-h) SMNS 50329, Temnodontosaurus $\mathrm{cf}$ trigonodon metacarpal II. Images in (a), (d), (e) and (g) are in normal transmitted light, (c) and (h) in cross-polarized light, and (b) and (f) in cross-polarized light using a lambda compensator. (a, b) Close-up of the cortical bone in the notched area. (c) Close-up of external (dorsal) cortical bone and adjacent interior cancellous bone. (d) Close-up of calcified cartilage cap and adjacent interior trabecular bone. (e) Close-up of the calcified cartilage cap and collapsed interior trabecular framework. (f) Close-up of the notched cortex. Note dorsoventral crushing of element. $(\mathrm{g}, \mathrm{h})$ Close-up of the internal (ventral) cortical bone and adjacent interior collapsed trabecular framework. Abbreviations: CC - calcified cartilage; FLB - fibrolamellar bone; FOR - foramen; PO - primary osteon; ShF - Sharpey's fibres. 
Table 1. Descriptive statistics: number of notched elements, Stenopterygius quadriscissus

\begin{tabular}{lcccccc}
\hline & Forelimb mean & Forelimb range & Forelimb sd & Hind limb mean & Hind limb range & Hind limb sd \\
\hline Stenopterygius & 3.7 & $2-6$ & 1.0 & 4.5 & $3-9$ & 1.0 \\
quadriscissus & $\mathbf{4 . 2}$ & $\mathbf{3 - 6}$ & $\mathbf{0 . 9}$ & $\mathbf{4 . 8}$ & $\mathbf{3 - 9}$ & $\mathbf{1 . 0 9}$ \\
\hline
\end{tabular}

*sd - standard deviation. Values in bold were calculated excluding juveniles from the sample.

latter is generally thinner than the tibia (taking into account the crushing the elements experienced), the cortical bone is more strongly vascularized throughout, presenting the 'osteoporotic' appearance typical of derived ichthyosaur bones (e.g. de Buffrénil \& Mazin, 1990; Kolb, Sánchez-Villagra \& Scheyer, 2011). In the tibia, the periosteal layer is less vascularized. Starting from around the centre of the elements, the orientation of the vascular cavities and the cortical canal system change from being arranged sub-parallel and perpendicular to the outer bone surface, respectively, to being angled towards the articular surface opposite to the notch. Sharpey's fibres (Fig. $3 g-h$ ), which are present in both sections throughout the periosteal bone, generally follow the vascular arrangement, changing from a perpendicular arrangement in the notch area to more oblique angles towards the opposite articular surface.

\section{3.c. Intraspecific variability in Stenopterygius quadriscissus}

Notching is present on the anterior edge of digit II in both the fore- and hind limbs of all specimens of Stenopterygius quadriscissus studied. In the forelimb, notching develops in a roughly proximal to distal sequence, radiale $>$ (distal carpal (dc) II $<>$ radius) $>$ mcII $>$ phalanges (digit II), with the terminal events in the series occurring variably in adults. Up to the second phalanx may be notched in S. quadriscissus; however, in most specimens the distal-most notched element is dcII (Table 1). Left-right asymmetry in the number of notches is very common: out of 13 specimens with both forelimbs adequately preserved, $7 / 13(54 \%)$ showed asymmetry. The within-individual difference in the number of notches on the right and left sides is never greater than one. The number and identity of notched elements is size dependent (Table 2). Notching is occasionally absent in the radius but present in more distal elements (e.g. radiale, dcII). This is ontogenetically dependent, found only in embryos and small juveniles, confirming the results of a previous interspecific study (Johnson, 1977). However, the radial notch is not restricted to the postnatal stages, sometimes developing prior to birth (e.g. SMNS 7402).

Notching is more variable in the hind limb than in the forelimb. The tibia is more frequently unnotched than the radius, and the two morphologies occur independently. When an ossification is present anterior to the tibia (Fraas, 1891; Maxwell, 2012) both it and the tibia are unnotched. As few as three notches are present in the hind limb (MHH 1981/13) (Table 1); this
Table 2. Partial correlations (forelimb), p-values above the diagonal, partial correlations below

\begin{tabular}{lccc}
\hline & Notches & Lower jaw & Number phalanges \\
\hline Notches & & $\mathbf{0 . 0 0 1}$ & 0.099 \\
Lower jaw & 0.353 & & 0.051 \\
Number phalanges & 0.182 & 0.215 & \\
\hline
\end{tabular}

$\mathrm{N}=41$. Values in bold were significant following Bonferroni correction.

Table 3. Partial correlations (hind limb)

\begin{tabular}{lccc}
\hline & Notches & Lower jaw & Number phalanges \\
\hline Notches & & 0.020 & 0.012 \\
Lower jaw & 0.284 & & 0.334 \\
Number phalanges & 0.309 & 0.118 & \\
\hline
\end{tabular}

No values were significant following Bonferroni correction. $\mathrm{N}=34$.

Table 4. Correlation between serial homologues, at constant body size

\begin{tabular}{lccc}
\hline & Forelimb & Hind limb & Lower jaw \\
\hline Forelimb & & 0.194 & $\mathbf{0 . 0 0 0 5 0}$ \\
Hind limb & 0.144 & 0.026 \\
Lower jaw & 0.388 & 0.249 & \\
\hline
\end{tabular}

Values in bold were significant following Bonferroni correction. $\mathrm{N}=40$.

is weakly correlated with size but the relationship is not significant (Table 3). In most specimens, the most distal notched element is the proximal phalanx of digit II, but up to the sixth phalanx may be notched (Table 1). Of the 13 specimens with hind limbs adequately preserved, $6 / 13(46 \%)$ show left-right asymmetry, but as in the forelimb, the within-individual difference is no greater than one. The hind limb has on average one notched element more than the forelimb.

In both the statistical analysis of the forelimb alone and that including the hind limb (Tables 2, 4), body size was the only significant predictor of the number of notched forelimb elements. The relationship between the variables was positive (larger specimens possessed a greater number of notched elements) (Fig. 4a). No variables were significant in predicting the number of notches in the hind limb (Table 3). The total number of phalanges explained the largest fraction of observed variance, and, as in the forelimb, the relationship was positive.

The significance of the observed increase in number of notches in the stratigraphically youngest specimens (Fig. 4b) was evaluated by calculating the probability of the increase observed in the late elegans Subzone being attributable to chance. Resampling the data to mimic 
(a)

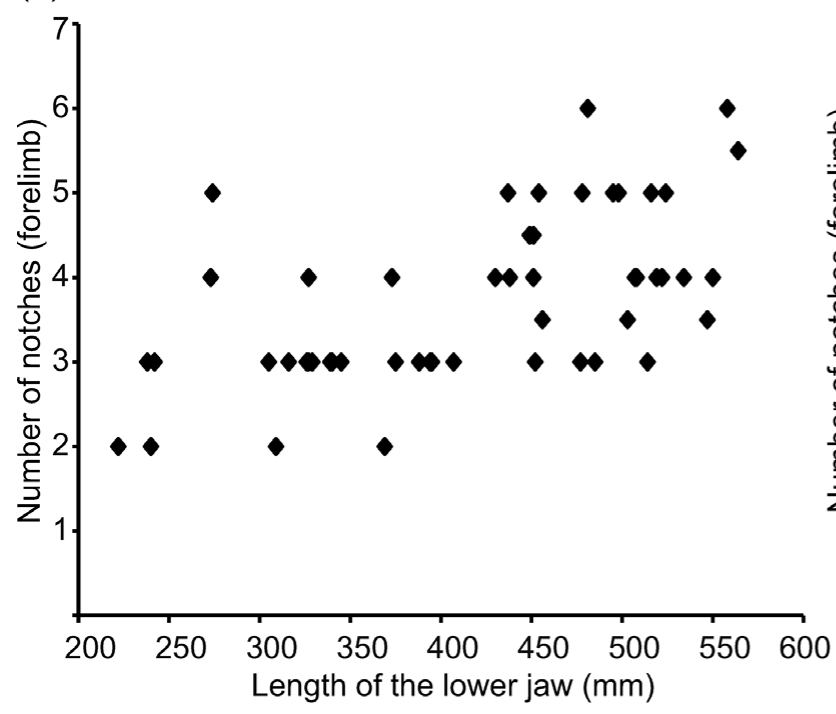

(b)

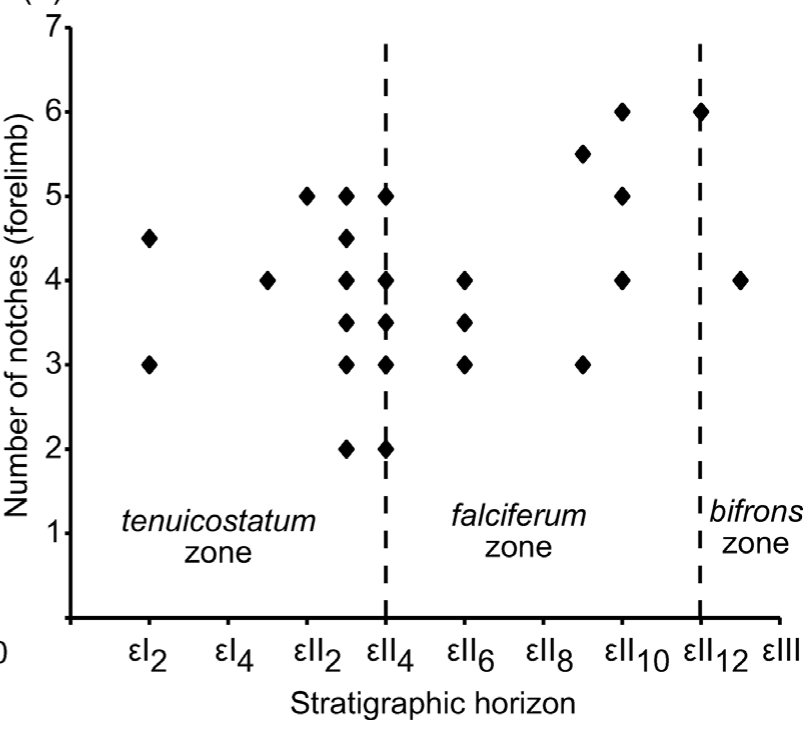

Figure 4. Number of notches in the forelimb of Stenopterygius quadriscissus (a) plotted against lower jaw length, a proxy for body size, and (b) number of notches in the forelimb plotted against stratigraphic provenance. The numbering of the beds follows a local scheme for the Posidonia Shale in southwestern Germany (see Urlichs, Wild \& Ziegler, 1979). The radius is always counted as notched, even when variable, such that the number of notches reflects the identity of the most distal notched element.

the number of adult specimens in the best-sampled time interval (late semicelatum Subzone; $\mathrm{N}=11$ ) suggested that the observed distribution pattern of specimens with the most notches in the forelimb is not different from that expected by chance.

\section{Discussion}

\section{4.a. Implications of histological, phylogenetic and intraspecific data}

Caldwell (1997b) challenged the hypothesis of homology of notches in the leading-edge elements of ichthyosaur limbs to the shafts of long bones, noting the onset of perichondral ossification was delayed along the anterior margin of the notched elements. The dorsal and ventral periostea ossified separately and later fused anteriorly (Caldwell, 1997b), in contrast to the early ossification of the perichondrium in the long bones of most extant diapsids. It has been argued that changes in element shape are related to the timing and nature of ossification (Blanco, Misof \& Wagner, 1998). In extant cetaceans with proximodistally shortened acropodial elements, phalangeal ossification proceeds through the formation of an initial ovoid ossification centre, followed by delayed perichondral ossification at the anterior or posterior margin (delta-shaped bone: Dawson, 2003), and lastly by ossification of the opposite margin. In some species, ossification remains arrested at the ovoid state in the distal phalanges, and ossification of the anterior and posterior perichondrium never occurs (Mellor et al. 2009). A heterochronic delay in the ossification of the phalangeal margins is consistent with the size-related increase in the number of notches seen in Stenopterygius quadriscissus (this study; Johnson, 1977). Although bone histology shows no indication for a fusion of separate dorsal and ventral periosteal layers or later development of the anterior phalangeal edge, we cannot rule out the possibility that these events occurred early in development, but that their traces were subsequently removed by internal bone remodelling. Thus, although the change in mode of ossification in the notched limb elements of derived ichthyosaurs appears to be mediated through heterochronic processes, examination of the histology of a growth series is needed to test this hypothesis.

The distribution of Sharpey's fibres throughout the periosteal layer of the Stenopterygius tibia indicates a close interface between the bone and surrounding connective tissue within the flipper, as expected. It is noteworthy that the thickness of the periosteal layer in the notched region of this element is well developed and the vascularity is reduced. These microstructures are in accordance with ossification induced by leadingedge stresses on the anterior digit, suggesting the notches were not foramina surrounded by fibrocartilage anteriorly (as proposed by Johnson, 1979). Cetaceans show proximodistal ankylosis of phalanges along the leading edge of the flipper in response to hydrodynamic stresses (Cooper \& Dawson, 2009), which are greatest along the anterior surface (Cooper et al. 2007a,b). The reduced porosity of the anterior periosteal layer of the tibia relative to the posterior margin implies that the hind limb of Stenopterygius may also experience leading-edge forces. The tibia of the intermediategrade ichthyosaur examined by de Buffrénil \& Mazin (1990) did not show this anteroposterior gradient in periosteal porosity, being osteoporotic throughout. The correlation between morphological changes related to thunniform swimming and microstructure of the 
limb elements promises to be an intriguing direction of future investigation into ichthyosaurian functional morphology.

Perichondral bone on the anterior surface of ichthyosaur limb elements is found in most Triassic and Early Jurassic genera. An almost continuous occurrence throughout the early record of ichthyosaurs, following a trend towards reduction and loss, suggests that the notches are phylogenetically conserved structures, homologous across the clade and, by extension, to the shaft of the long bone in terrestrial tetrapods (von Huene, 1922). However, the position of notched elements varies extensively along the proximodistal axis of the limb and also between the fore- and hind limbs, and this creates problems if a notch is considered a property linked with a given element. For instance, the anterior surface of dcII is a novel expression domain for a long bone-like peripheral shaft; likewise, the first phalanx of the leading-edge digit loses and reevolves a notched morphology multiple times. While the latter pattern can be explained through differences in timing of ossification, the former can only be reconciled with homology if the notched morphology is viewed to be the result of an identity shift within a series of structures. This is analogous to qualitative and quantitative changes in the number and identity of elements in the vertebral column, where boundaries between elements showing a given morphology shift along the anterior-posterior axis over evolutionary time (e.g. Buchholtz, 2007; Müller et al. 2010). We discuss a hypothesis based on molecular developmental mechanisms in the following section that elucidates how this type of change may have arisen.

\section{4.b. Possible mechanistic underpinnings of mesopodialization in ichthyosaurs}

Developmental biology can provide a complementary perspective on how the patterning of the ancestral tetrapod limb could have been modified to give rise to the remarkably divergent ichthyosaurian limb. Limb patterning is understood through the study of two model systems: the house mouse, Mus musculus, and the domestic chicken, Gallus gallus (Tabin \& Wolpert, 2007; Towers \& Tickle, 2009; Zeller, López-Ríos \& Zuniga, 2009; Woltering \& Duboule, 2010). Despite large morphological differences between the forelimbs of these two models, they show remarkable similarity in the genetic networks underlying limb development, strongly suggesting tetrapod limb diversity is achieved through modifications to existing networks and known genes, and not through the activity of genes unique to limb development in that species or clade (Woltering \& Duboule, 2010; Young et al. 2011). The relationship between progressive mesopodialization of the acropodium and zeugopodium and acquisition of a notched morphology in the mesopodium in ichthyosaur limb evolution are areas in which developmental biology can provide information on potential pathways of character evolution. In particular, mesopodialization is a process for which a great deal of information is available.

Hypotheses put forward to explain mesopodialization of the ichthyosaur acropodium centre around the Hox family of genes. The transcription of Hox genes in specific areas of the developing embryo is closely associated with acquisition of the appropriate positional identity of resulting structures (Swalla, 2006). This is also true in the limb, in which a specific pattern of Hox expression dictates element identity along the proximodistal axis prior to the differentiation of skeletal tissues (Woltering \& Duboule, 2010). The expression of a combination of HoxA11 and HoxD10 HoxD12 indicates zeugopodial identity; HoxA13 and little to no expression of HoxD genes characterize the mesopodium; HoxA13 and HoxD13 are expressed throughout the acropodium, while all but the region producing the most anterior digit express HoxD10 HoxD12 (Woltering \& Duboule, 2010) (Fig. 5a-b). Theoretically, changing the proximodistal location of a given Hox expression pattern should result in a predictable proximodistal transformation of element identity along the limb axis (i.e. a homeotic transformation). In derived ichthyosaurs, the mesopodialization of the acropodium could be owing to a distal shift of mesopodial Hox gene expression into the acropodium. Similarly, a proximal shift in the autopodial profile of Hox expression could produce zeugopodial elements with mesopodial characteristics (Wagner \& Chiu, 2001) (Fig. 5c). Unfortunately, experiments examining the effect of modifications to Hox gene expression in mice argue against this hypothesis. Although reduced acropodial expression of HoxD genes should theoretically induce a homeotic transformation resulting in the mesopodialization of the metapodials and phalanges, in reality these elements become shorter but retain their long bone morphology (Reno et al. 2008; Montavon et al. 2011).

The second hypothesis involves changes to the Hox gene products themselves (Fig 5d). A HoxD13 mutant, synpolydactyly homologue ( $s p d h)$, exists that results in a homeotic-like transformation of metapodial elements to mesopodialized elements in humans and mice (Muragaki et al. 1996; Horsnell et al. 2006; Cocquempot et al. 2009). Instead of modifying the transcription of HoxD13, the spdh mutation changes the protein coding sequence by increasing the number of alanine residues within the polyalanine tract of the protein (Bruneau et al. 2001; Villavicencio-Lorini et al. 2010). The mutant phenotype exhibits proximal acropodial elements that resemble those in the mesopodium, becoming shorter, with reduced perichondral bone (Muragaki et al. 1996; Horsnell et al. 2006). Increasing the number of alanine repeats increases the severity of the mutant phenotype (Goodman et al. 1997; Villavicencio-Lorini et al. 2010). The reduction of perichondral bone observed in the mutant phenotype is driven by the interaction between the HoxD13 protein and Runx2, a protein that regulates the ossification of the perichondrium (Villavicencio-Lorini et al. 2010). 
(a)

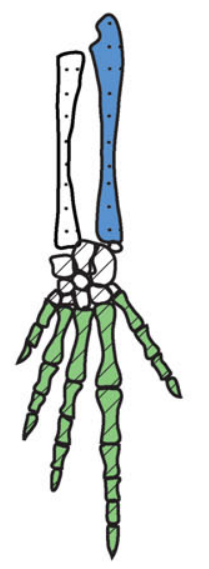

(b)

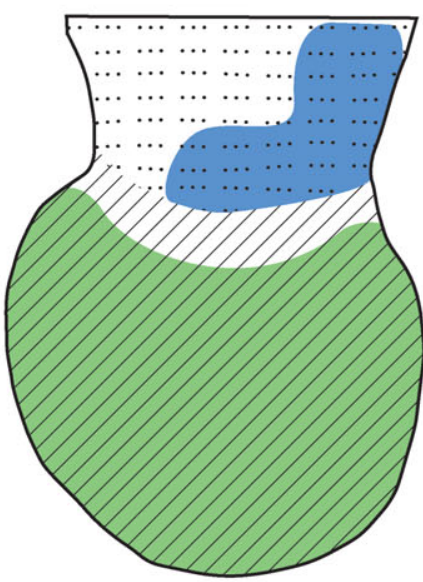

(c)

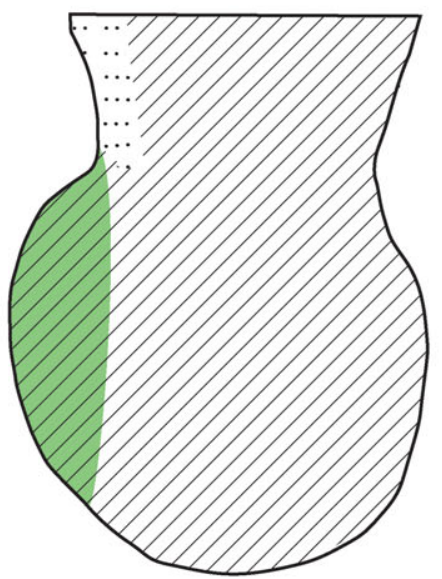

(d)

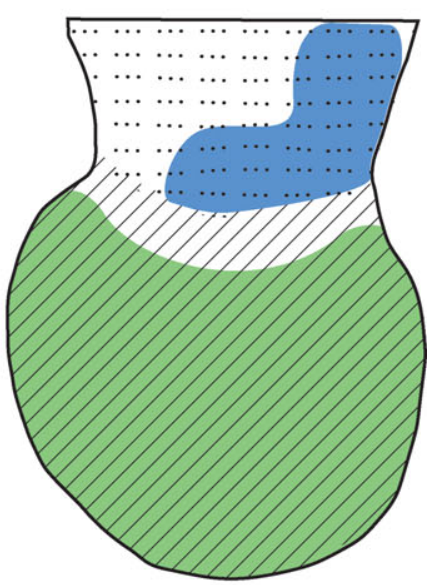

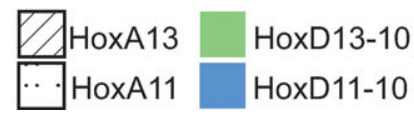

Figure 5. (Colour online) Regionalization of Hox gene expression (a) correlated to adult limb regions in a terrestrial diapsid; (b) in the limb bud of a mouse; (c) expression profile expected in the ichthyosaur limb bud based on morphological change driven by transcriptional change in Hox expression; and (d) expression profile expected in the ichthyosaur limb bud if changes in Hox protein structure are driving morphological change. Anterior is to the left.

HoxD13 and Runx2 are produced in the cytoplasm but act in the nucleus, and the expansion of the polyalanine tract of HoxD13 prevents this migration. Increasing the number of alanine residues proportionally increases the retention of HoxD13 and Runx 2 proteins outside the nucleus, where they are inactive (Villavicencio-Lorini et al. 2010). With the Runx 2 protein sequestered, the ossification of the perichondrium is delayed, resulting in shorter, more nodular bones (Villavicencio-Lorini et al. 2010).

The polyalanine tract of HoxD13 is not found in all tetrapods but is thought to have arisen prior to the origin of amniotes (Anan et al. 2007), and thus its presence can be inferred in ichthyosaurs. Natural variation in the length of the tract results in predictable changes similar to those described based on the $s p d h$ phenotype. Within mammals, an expansion of the polyalanine tract occurred during the evolution of the cetacean HoxD13 gene (Wang et al. 2008). It is reasonable to suggest that an increase in the number of alanine residues in the cetacean HoxD13 could result in the initiation of mesopodialization of the cetacean acropodium, including shorter, more nodular phalanges, and delayed or absent perichondral ossification (Dawson, 2003; Mellor et al. 2009).

The gradual mesopodialization of the limb in ichthyosaurs would have been associated with proximodistal homogenization of Hox activity, either through altered expression domains or through altered protein structure. The notches along the margins of the limb could result from either reduced penetrance of the expanded polyalanine phenotype along the periphery of the limb, or through dilute expression of zeugopodial and acropodial cues. These may have been conserved via interaction between proximodistal and anteroposterior axis specification mechanisms, effected through signalling centres on the distal and posterior margins of the limb (apical ectodermal ridge and the zone of polarizing activity) (Zeller, López-Ríos \& Zuniga, 2009). In contrast, a strictly mechanical hypothesis for the notching of the anterior digit, for instance the presence of dorsoventral nerves and/or blood vessels creating the notching, is doubtful: notches are more numerous in the hind limb than the forelimb in most ichthyosaurs, but at the same time the hind limb is reduced both in size, number of elements, and theoretically also in function (Buchholtz, 2001).

Although the above discussion is speculative, it investigates the existing developmental data in light of the phenotypes seen in ichthyosaurs. Further developmental research is needed on the relationship between the transcription of genes relevant to limb development, their molecular biology and their effects on phenotype, especially the mesopodial region. The structure of the HoxD13 polyalanine tract over a broader range of diapsids would also provide information on its conservation and morphogenetic role in non-mammalian systems. Improved understanding of the morphology and evolution of highly derived phenotypes, such as the ichthyosaur limb, can provide a new perspective on the morphogenesis of less divergent forms.

\section{Conclusions}

We find strong support for the opinion of earlier workers that the notched morphology seen in the phalangeal elements of Early Jurassic ichthyosaurs is homologous to the shaft of the long bones in terrestrial tetrapods (von Huene, 1922; Motani, 1999b) using phylogenetic arguments. However, because the presence of notches on the anterior edge of limb elements does not appear to be irreversibly associated 
with element identity based on proximodistal position, further explanations are required. Therefore, we propose a morphogenetic hypothesis that might underlie the loss of proximodistal identity (mesopodialization) of ichthyosaurian limbs. Intraspecific data from Stenopterygius quadriscissus is consistent with these conclusions: although the number of notches varies within this species, the significant correlation with body size suggests that this morphology is caused by a delay in perichondral ossification, as has been reported in extant cetaceans. Although the examination of the histology and microstructure of notched elements could not confirm the observation of delayed perichondral ossification along the anterior phalangeal margin in Stenopterygius (Caldwell, 1997b), it did not suggest that the periosteum lining the notch was qualitatively different from that on the dorsal and ventral phalangeal surfaces.

Drawing on multiple lines of evidence to understand the evolution and function of unique morphologies is relatively new to studies of marine reptile palaeontology. However, as demonstrated here using phylogenetic, intraspecific and histological data, this approach holds great promise as a way to understand trends in the evolution and development of adaptations to a secondarily aquatic way of life. In the future, such techniques could be used to identify different mechanistic underpinnings of convergence between independent marine radiations.

Acknowledgements. Thanks to R. Schoch, M. SánchezVillagra and H. Larsson for discussion, R. Schoch and J. Müller for logistical support, P. Havlik (GeologischPaläontologisches Institut und Museum, Universität Tübingen), R. Hauff (Urwelt Museum Hauff), R. Brocke (Senckenberg Forschungsinstitut und Naturmuseum Frankfurt), J. Ebbestad (Evolutionsmuseet, Uppsala Universitet) and U. Göhlich (Naturhistorisches Museum Wien) for collections access, and to B. Kear for coordinating this special issue. The comments of two anonymous reviewers significantly improved this manuscript. This project was funded through Natural Sciences and Engineering Research Council of Canada (NSERC) and Alexander von Humboldt postdoctoral fellowships (E. M.), and the Swiss National Science Foundation (T. M. S., 31003A 127053).

\section{References}

Anan, K., Yoshida, N., KataOKa, Y., Sato, M., Ichise, H., NASU, M. \& UEDA, S. 2007. Morphological change caused by loss of the taxon-specific polyalanine tract in Hoxd-13. Molecular Biology and Evolution 24, 281-7.

Archer, C. W., Dowthwaite, G. P. \& Francis-West, P. 2007. Joint formation. In Fins into Limbs (ed. B. K. Hall), pp. 109-17. Chicago: University of Chicago Press.

Blanco, M. J., Misof, B. Y. \& Wagner, G. P. 1998. Heterochronic differences of Hoxa-11 expression in Xenopus fore- and hind limb development: evidence for lower limb identity of the anuran ankle bones. Development Genes and Evolution 208, 175-87.

Bruneau, S., Johnson, K. R., YAMAMOTO, M., KuRoIWA, A. \& Duboule, D. 2001. The mouse Hoxd13 $3^{\mathrm{spdh}}$ mutation, a polyalanine expansion similar to human type II synpolydactyly (SPD), disrupts the function but not the expression of other Hoxd genes. Developmental Biology 237, 345-53.

BuchHolTz, E. A. 2001. Swimming styles in Jurassic ichthyosaurs. Journal of Vertebrate Paleontology 21, 6173.

BuCHHOLTZ, E. A. 2007. Modular evolution of the cetacean vertebral column. Evolution and Development 9, 27889.

CALDWELl, M. W. 1997a. Limb ossification patterns of the ichthyosaur Stenopterygius, and a discussion of the proximal tarsal row of ichthyosaurs and other neodiapsid reptiles. Zoological Journal of the Linnean Society 120 , $1-25$.

CALDWELL, M. W. 1997b. Modified perichondral ossification and the evolution of paddle-like limbs in ichthyosaurs and plesiosaurs. Journal of Vertebrate Paleontology 17, 534-47.

Caldwell, M. W. 2002. From fins to limbs to fins: limb evolution in fossil marine reptiles. American Journal of Medical Genetics 112, 236-49.

CAMP, C. L. 1980. Large ichthyosaurs from the Upper Triassic of Nevada. Palaeontographica Abteilung A 170, 139-200.

CANOVILle, A. \& LaURin, M. 2010. Evolution of humeral microanatomy and lifestyle in amniotes, and some comments on palaeobiological inferences. Biological Journal of the Linnean Society 100, 384-406.

Chinsamy, A. \& RAATH, M. A. 1992. Preparation of fossil bone for histological examination. Palaeontologia Africana 29, 39-44.

Cocquempot, O., Brault, V., Babinet, C. \& Herault, Y. 2009. Fork stalling and template switching as a mechanism for polyalanine tract expansion affecting the DYC mutant of HOXD13, a new murine model of synpolydactyly. Genetics 183, 23-30.

CoOper, L. N., Berta, A., DAWson, S. D. \& ReIDENBERG, J. S. 2007a. Evolution of hyperphalangy and digit reduction in the cetacean manus. Anatomical Record 290, 654-72.

COOPER, L. N., DAWson, S. D., REIDENBERG, J. S. \& BerTA, A. $2007 b$. Neuromuscular anatomy and evolution of the cetacean forelimb. Anatomical Record 290, 1121-37.

CoOper, L. N. \& Dawson, S. D. 2009. The trouble with flippers: a report on the prevalence of digital anomalies in Cetacea. Zoological Journal of the Linnean Society 155, 722-35.

DAl SASso, C. \& PinNA, G. 1996. Besanosaurus leptorhynchus n. gen. n. sp., a new shastasaurid ichthyosaur from the Middle Triassic of Besano (Lombardy, N. Italy). Paleontologia Lombarda, Nuova Serie 4, 1-23.

DAwson, S. D. 2003. Patterns of ossification in the manus of the harbor porpoise (Phocoena phocoena): hyperphalangy and delta-shaped bones. Journal of Morphology 258, 200-6.

DE BufFRÉNIL, V. \& MAZIN, J.-M. 1990. Bone histology of the ichthyosaurs: comparative data and functional interpretation. Paleobiology 16, 435-47.

De la Beche, H. T. \& Conybeare, W. D. 1821. Notice of the discovery of a new fossil animal, forming a link between the Ichthyosaurus and crocodile, together with general remarks on the osteology of the Ichthyosaurus. Transactions of the Geological Society, London 5, 55994.

Evans, M. 2010. The roles played by museums, collections and collectors in the early history of reptile palaeontology. In Dinosaurs and Other Extinct Saurians: A 
Historical Perspective (eds R. T. J. Moody, E. Buffetaut, D. Naish \& D. M. Martill), pp. 5-29. London: Geological Society.

FEDAK, T. J. \& Hall, B. K. 2004. Perspectives on hyperphalangy: patterns and processes. Journal of Anatomy 204, 151-63.

Fischer, V., MASURE, E., ARKHANGElSKY, M. S. \& Godefroit, P. 2011. A new Barremian (Early Cretaceous) ichthyosaur from Western Russia. Journal of Vertebrate Paleontology 31, 1010-25.

FRAAS, E. 1891. Ichthyosaurier der süddeutschen Trias- und Jura- Ablagerungen. Tübingen: H. Laupp.

Goodman, F. R., Mundlos, S., Muragaki, Y., Donnai, D., GiovanNUCCI-UZIELLI, M. L., LAPI, E., MAJEWSKI, F., McGaughran, J., McKeown, C., Reardon, W., Upton, J., Winter, R. M., Olsen, B. R. \& SCAMbler, P. J. 1997. Synpolydactyly phenotypes correlate with size of expansions in HOXD13 polyalanine tract. Proceedings of the National Academy of Sciences $\mathbf{9 4}$, 7458-63.

Horsnell, K., Ali, M., Malik, S., Wilson, L., Hall, C., DeBeER, P. \& CROW, Y. 2006. Clinical phenotype associated with homozygosity for a HOXD13 7residue polyalanine tract expansion. European Journal of Medical Genetics 49, 396-401.

VON HuENE, F. 1922. Die Ichthyosaurier des Lias und ihre Zusammenhänge. Berlin: Verlag von Gebrüder Borntraeger.

JOHNSON, R. 1977. Size independent criteria for estimating relative age and the relationship among growth parameters in a group of fossil reptiles (Reptilia: Ichthyosauria). Canadian Journal of Earth Sciences 14, 1916-24.

JOHNSON, R. 1979. The osteology of the pectoral complex of Stenopterygius Jaekel (Reptilia: Ichthyosauria). Neues Jahrbuch für Geologie und Paläontologie. Abhandlungen 159, 41-86.

KIPRIJANOFF, W. 1881. Studien über die fossilen Reptilien Russlands. Theil 1. Gattung Ichthyosaurus König aus dem Sewerischen Sandstein oder Osteolith der Kreide-Gruppe. Mémoires de l'Académie Impériale des Sciences de Saint-Pétersbourg 28, 1-103.

Kolb, C., SÁnchez-Villagra, M. R. \& Scheyer, T. M. 2011. The paleohistology of the basal ichthyosaur Mixosaurus Baur, 1887 (Ichthyopterygia, Mixosauridae) from the Middle Triassic: palaeobiological implications. Comptes Rendus Palevol 10, 403-11.

LOPUCHOWYCZ, V. B. \& MASSARE, J. A. 2002. Bone microstructure of a Cretaceous ichthyosaur. Paludicola 3, 139-47.

Maisch, M. W. \& MATZKe, A. T. 1998. Observations on Triassic ichthyosaurs. Part IV: on the forelimb of Mixosaurus Baur, 1887. Neues Jahrbuch für Geologie und Paläontologie, Abhandlungen 209, 247-72.

MAXWELL, E. E. 2012. Unraveling the influences of softtissue flipper development on skeletal variation using an extinct taxon. Journal of Experimental Zoology (Molecular and Developmental Evolution) 318, 545-54.

MaXwell, E. E. \& DeCECCHI, T. A. 2012. Ontogenetic and stratigraphic influence on observed phenotypic integration in the limb skeleton of a fossil tetrapod. Paleobiology 39, 123-34.

Maxwell, E. E., Fernández, M. S. \& SCHOCH, R. R. 2012. First diagnostic marine reptile remains from the Aalenian (Middle Jurassic): a new ichthyosaur from southwestern Germany. PLoS ONE 7, e41692.

MCGowAN, C. 1973. Differential growth in three ichthyosaurs: Ichthyosaurus communis, I. breviceps, and Stenopterygius quadriscissus (Reptilia, Ichthyosauria).
Life Sciences Contributions, Royal Ontario Museum 93, $1-21$.

MCGowAN, C. 1974. A revision of the latipinnate ichthyosaurs of the Lower Jurassic of England (Reptilia: Ichthyosauria). Life Sciences Contributions, Royal Ontario Museum 100, 1-30.

MCGOWAN, C. \& MOTANI, R. 2003. Ichthyopterygia. Handbook of Paleoherpetology (ed. H.-D. Sues). München: Verlag Dr. Friedrich Pfeil.

Mellor, L., CoOper, L. N., Torre, J. \& Brownell, R. L. J. 2009. Paedomorphic ossification in porpoises with an emphasis on the vaquita (Phocoena sinus). Aquatic Mammals 35, 193-202.

Montavon, T., Soshnikova, N., Mascrez, B., Joye, E., Thevenet, L., SPlinter, E., DE LAAT, W., SPITz, F. \& DUBOULE, D. 2011. A regulatory archipelago controls Hox genes transcription in digits. Cell 147, 1132-45.

MOTANI, R. 1997. New information of the forefin of Utatsusaurus hataii (Ichthyosauria). Journal of Paleontology 71, 475-9.

Motani, R. 1998. First complete forefin of the ichthyosaur Grippia longirostris from the Triassic of Spitsbergen. Palaeontology 41, 591-9.

MOTANI, R. 1999a. On the evolution and homologies of ichthyopterygian forefins. Journal of Vertebrate Paleontology 19, 28-41.

MOTANI, R. 1999b. Phylogeny of the Ichthyopterygia. Journal of Vertebrate Paleontology 19, 472-95.

MÜller, J., SCHEYER, T. M., HEAD, J. J., BARRETT, P. M., Werneburg, I., Ericson, P. G. E., Pol, D. \& SÁNCHEZ-VILlaGRA，M. R. 2010. Homeotic effects, somitogenesis and the evolution of vertebral numbers in recent and fossil amniotes. Proceedings of the National Academy of Sciences of the United States of America 107, 2118-23.

MuragaKi, Y., Mundlos, S., Upton, J. \& OlsEN, B. R. 1996. Altered growth and branching patterns in synpolydactyly caused by mutations in HOXD13. Science 272, 548-51.

Nicholls, E. L. \& Brinkman, D. B. 1995. A new ichthyosaur from the Triassic Sulphur Mountain Formation of British Columbia. In Vertebrate Fossils and the Evolution of Scientific Concepts (ed. W. A. S. Sarjeant), pp. 521-35. Amsterdam: Gordon and Breach.

QuinN, G. P. \& KeOUGH, M. J. 2002. Experimental Design and Data Analysis for Biologists. Cambridge: Cambridge University Press.

R Development CORE TEAM. 2011. R: a language and environment for statistical computing. Vienna, Austria: R Foundation for Statistical Computing.

REISZ, R. R. 1981. A diapsid reptile from the Pennsylvanian of Kansas. Special Publication of the Museum of Natural History, University of Kansas 7, 1-74.

Reno, P. L., McCollum, M. A., Cohn, M. J., Meindl, R. S., HAMrick, M. \& LoveJoy, C. O. 2008. Patterns of correlation and covariation of anthropoid distal forelimb segments correspond to Hoxd expression territories. Journal of Experimental Zoology (Molecular and Developmental Evolution) 310B, 240-58.

SAnder, P. M., Chen, X., Cheng, L. \& WAng, X. 2011. Short-snouted toothless ichthyosaur from China suggests Late Triassic diversification of suction feeding ichthyosaurs. PLoS ONE 6, e19480.

SwALLA, B. J. 2006. Building divergent body plans with similar genetic pathways. Heredity 97, 235-43.

TABIN, C. \& WOLPERT, L. 2007. Rethinking the proximodistal axis of the vertebrate limb in the molecular era. Genes and Development 21, 1433-42. 
Thewissen, J. G. M. \& TAYlor, M. A. 2007. Aquatic adaptations in the limbs of amniotes. In Fins into Limbs (ed. B. K. Hall), pp. 310-22. Chicago: University of Chicago Press.

Thorne, P. M., RutA, M. \& Benton, M. J. 2011. Resetting the evolution of marine reptiles at the Triassic-Jurassic boundary. Proceedings of the National Academy of Sciences of the United States of America 108, 833944.

Towers, M. \& TICKLE, C. 2009. Growing models of vertebrate limb development. Development 136, 17990.

URLICHS, M., WILD, R. \& ZIEGLER, B. 1979. Fossilien aus Holzmaden. Stuttgarter Beiträge zur Naturkunde Serie C 11, 1-34.

VillaVicencio-Lorini, P., Kuss, P., Friedrich, J., HauPT, J., FArooQ, M., TÜrkmen, S., Duboule, D., Hecht, J. \& MundLos, S. 2010. Homeobox genes d11-d13 and a13 control mouse autopod cortical bone and joint formation. Journal of Clinical Investigation 120, 19942004.

WAGNeR, G. P. \& ChiU, C.-H. 2001. The tetrapod limb: a hypothesis of its origin. Journal of Experimental
Zoology (Molecular and Developmental Evolution) 291B, 226-40.

Wang, Z., Yuan, L., Rossiter, S. J., Zuo, X., Ru, B., ZhONG, H., HAN, N., JONES, G., JePson, P. D. \& ZHANG, S. 2008. Adaptive evolution of 5' HoxD genes in the origin and diversification of the cetacean flipper. Molecular Biology and Evolution 26, 613-22.

WOLTERING, J. M. \& DuBOULE, D. 2010. The origin of digits: expression patterns versus regulatory mechanisms. Developmental Cell 18, 526-32.

Young, R. L., Bever, G. S., WANG, Z. \& WAGNER, G. P. 2011. Identity of the avian wing digits: problems resolved and unsolved. Developmental Dynamics 240, 1042-53.

ZELLER, R., LÓPEZ-RÍOS, J. \& ZUNIGA, A. 2009. Vertebrate limb bud development: moving towards integrative analysis of organogenesis. Nature Reviews Genetics 10, $845-58$.

ZhU, J., ZhANG, Y.-T., AlBer, M. S. \& NeWMAN, S. A. 2010. Bare bones pattern formation: a core regulatory network in varying geometries reproduces major features of vertebrate limb development and evolution. PLOS ONE 5, e10892. 
Geological Magazine

An evolutionary and developmental perspective on the loss of regionalization in the limbs of derived ichthyosaurs

E. E. Maxwell, T. M. Scheyer and D. A. Fowler

\section{Supplementary material}

Table S1. List of specimens examined

(a) Staatliches Museum für Naturkunde Stuttgart, Germany

SMNS 7402B, SMNS 7402, SMNS 55109, SMNS 54818, SMNS 57009, SMNS 56860, SMNS 54872, SMNS 50183, SMNS 59706, SMNS unnumbered, SMNS 54819, SMNS 56615, SMNS 50003, SMNS 80116, SMNS 56631, SMNS 51471, SMNS 57200, SMNS 54051, SMNS 81958, SMNS 55933, SMNS 80062, SMNS 54026, SMNS 58881, SMNS 51133, SMNS 55934, SMNS 56856, SMNS 51552, SMNS 3775, SMNS 56584, SMNS 80433, SMNS 15033, SMNS 55343, SMNS 53424, SMNS 51142, SMNS 55748, SMNS 50165, SMNS 80115, SMNS 6293, SMNS 52036, SMNS 10460, SMNS 54064, SMNS 51948, SMNS 50963, SMNS 16811, SMNS 53001

(b) Geologisch-Paläontologisches Institut und Museum, Universität Tübingen, Germany

GPIT IRE/208, GPIT RE/7300, GPIT RE/7299, GPIT TS, GPIT RE/7298, GPIT RE/7301, GPIT 1491/8, GPIT 1491/2, GPIT 1491/9, GPIT $1491 / 1$

(c) Urwelt Museum Hauff, Holzmaden, Germany MHH 2c, MHH 1981/13, MHH 1981/33

(d) Evolutionsmuseet Paleontologi, Uppsala Universitet, Sweden PMU R158, PMU R435, PMU R153

(e) Senckenberg Forschungsinstitut und Naturmuseum Frankfurt, Germany SMF 2, SMF457

(f) Naturhistorisches Museum Wien, Austria

NHMW A3802, NHMW 1882/0026/4083 
Table S2. Sequence of loss of perichondral bone in the limbs of ichthyosaurs.

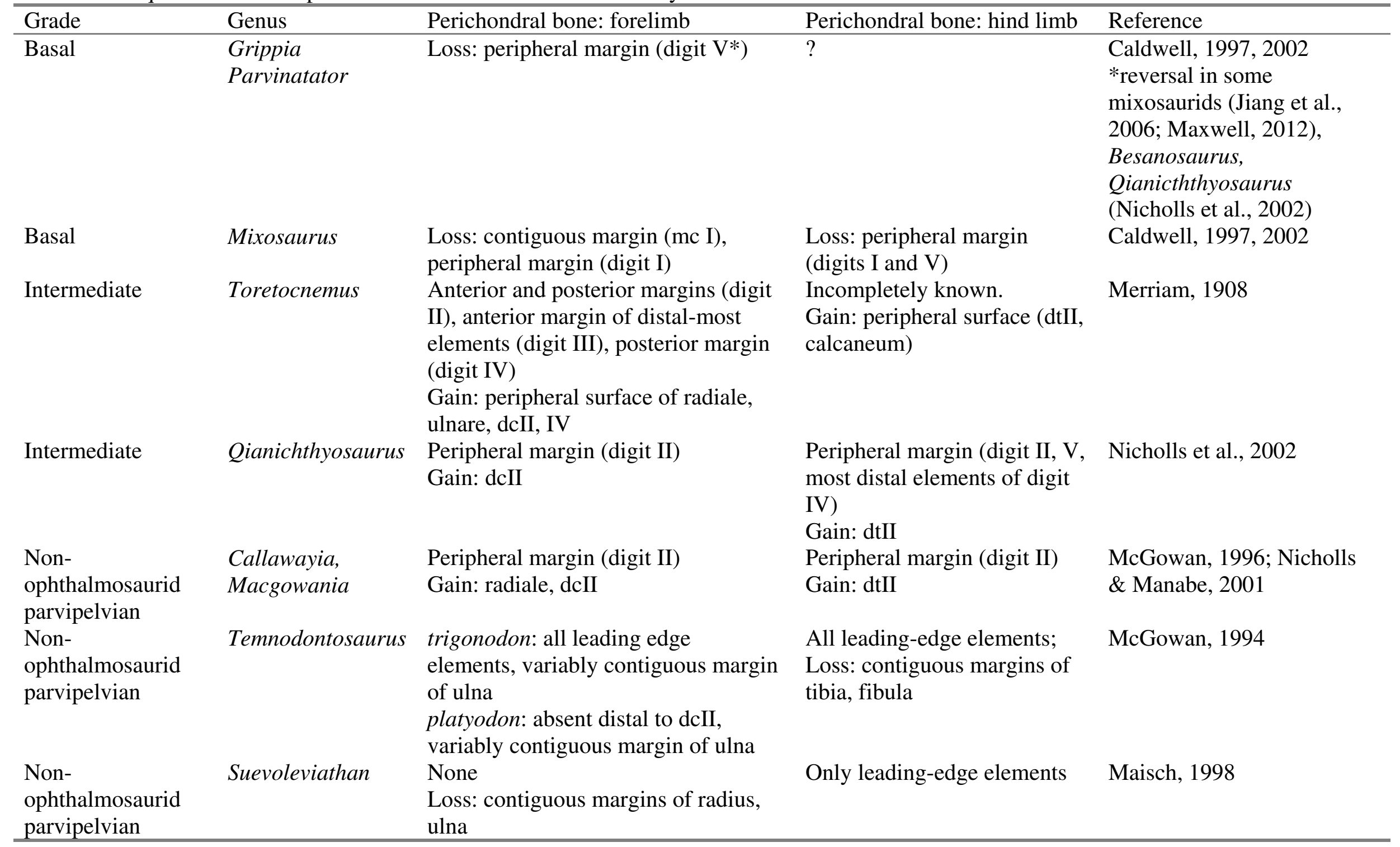




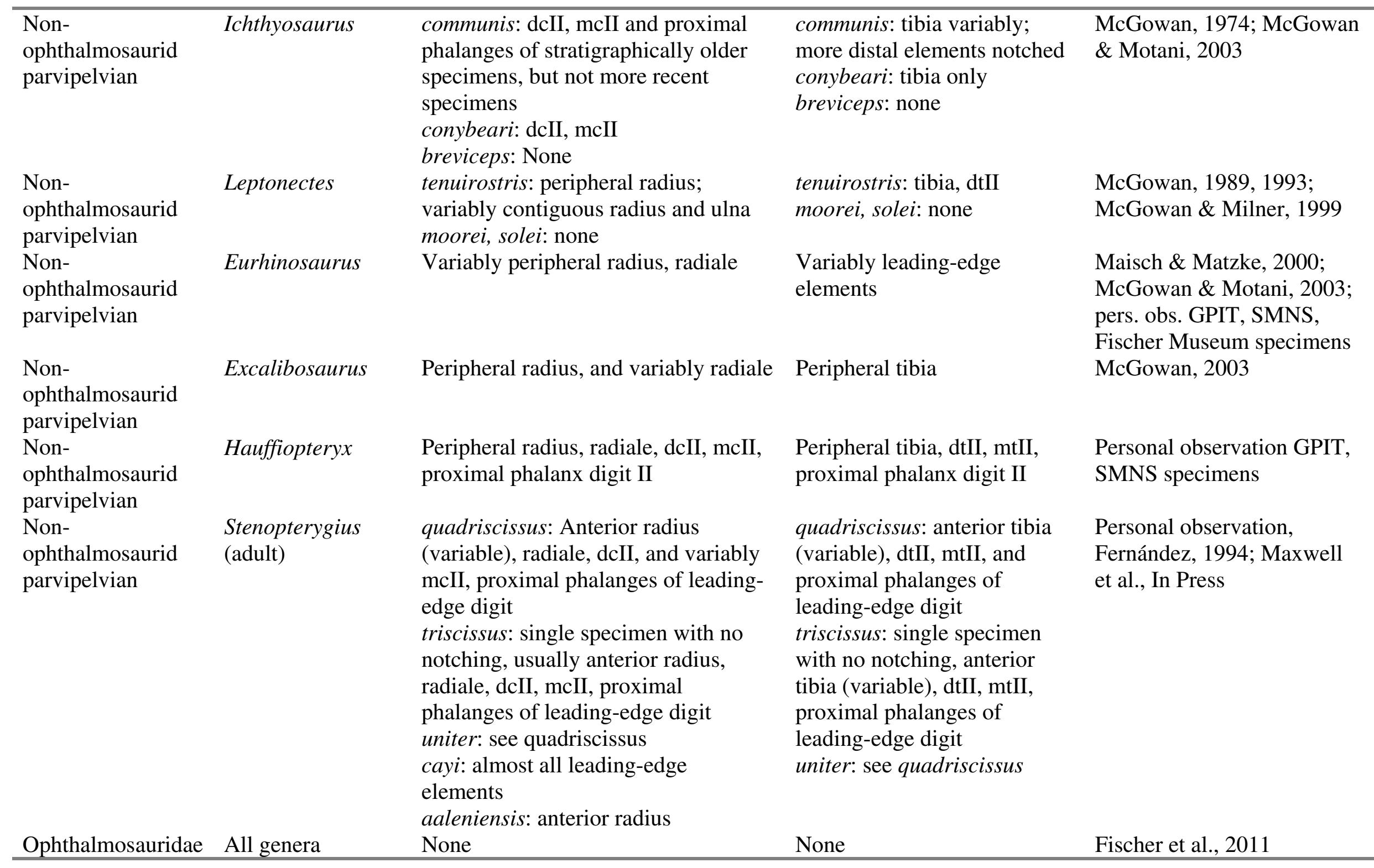




\section{References}

CALDWELl, M. W. 1997. Modified perichondral ossification and the evolution of paddle-like limbs in ichthyosaurs and plesiosaurs. Journal of Vertebrate Paleontology 17, 534-547.

CALDWELl, M. W. 2002. From fins to limbs to fins: limb evolution in fossil marine reptiles. American Journal of Medical Genetics 112, 236249.

FERNÁNDEZ, M. S. 1994. A new long-snouted ichthyosaur from the Early Bajocian of Neuquén Basin (Argentina). Ameghiniana 31, $291-297$. Fischer, V., MAsure, E., ARkhangelsky, M. S. \& Godefroit, P. 2011. A new Barremian (Early Cretaceous) ichthyosaur from Western Russia. Journal of Vertebrate Paleontology 31, 1010-1025.

JiAng, D.-Y., Schmitz, L., HAO, W.-C. \& SUN, Y.-L. 2006. A new mixosaurid ichthyosaur from the Middle Triassic of China. Journal of Vertebrate Paleontology 26, 60-69.

MAISCH, M. W. 1998. A new ichthyosaur genus from the Posidonia Shale (Lower Toarcian, Jurassic) of Holzmaden, SW-Germany with comments on the phylogeny of post-Triassic ichthyosaurs. Neues Jahrbuch für Geologie und Paläontologie Abhandlungen $209,47-78$.

MAISCH, M. W. \& MATZKE, A. T. 2000. The Ichthyosauria. Stuttgarter Beiträge zur Naturkunde Serie B (Geologie und Paläontologie) 298, 1159.

MAXWELL, E. E. 2012. Unraveling the influences of soft-tissue flipper development on skeletal variation using an extinct taxon. Journal of Experimental Zoology (Molecular and Developmental Evolution) 318, 545-554.

MAXwell, E. E., FernándeZ, M. S. \& SCHOCH, R. R. 2012. First diagnostic marine reptile remains from the Aalenian (Middle Jurassic): a new ichthyosaur from southwestern Germany. PLoS ONE 7, e41692. doi:10.1371/journal.pone.0041692.

MCGowAN, C. 1989. Leptopterygius tenuirostris and other long-snouted ichthyosaurs from the English Lower Lias. Palaeontology 15, $429-436$.

McGowAn, C. 1993. A new species of large, long-snouted ichthyosaur from the English lower Lias. Canadian Journal of Earth Sciences 30,

1197-1204.

MCGowan, C. 1994. Temnodontosaurus risor is a juvenile of T. platyodon (Reptilia: Ichthyosauria). Journal of Vertebrate Paleontology 14, 472-479.

MCGowan, C. 1996. A new and typically Jurassic ichthyosaur from the Upper Triassic of British Columbia. Canadian Journal of Earth Sciences 33, 24-32.

McGowan, C. \& Milner, A. C. 1999. A new Pliensbachian ichthyosaur from Dorset, England. Palaeontology 42, 761-768.

McGowan, C. 2003. A new specimen of Excalibosaurus from the English Lower Jurassic. Journal of Vertebrate Paleontology 23, $950-956$.

McGowan, C. \& Motani, R. 2003. Ichthyopterygia. München: Verlag Dr. Friedrich Pfeil.

MERRIAM, J. C. 1908. Triassic Ichthyosauria with special reference to the American forms. Memoirs of the University of California 1, 1-196. Nicholls, E. L. \& MANABE, M. 2001. A new genus of ichthyosaur from the Late Triassic Pardonet Formation of British Columbia: bridging the Triassic-Jurassic gap. Canadian Journal of Earth Sciences 38, 983-1002. 
Nicholls, E. L., WeI, C. \& MANABE, M. 2002. New material of Qianichthyosaurus Li, 1999 (Reptilia, Ichthyosauria) from the Late Triassic of Southern China, and implications for the distribution of Triassic ichthyosaurs. Journal of Vertebrate Paleontology 22, 759-765. 